\title{
INTERNALISASI STANDAR HAM INTERNASIONAL DALAM PENGUJIAN UNDANG-UNDANG OLEH MAHKAMAH KONSTITUSI
}

\author{
Titon Slamet Kurnia*
}

\author{
Bagian Hukum Tata Negara, Fakultas Hukum, Universitas Kristen Satya Wacana, Salatiga \\ Jalan Diponegoro 52-60, Salatiga Jawa Tengah, 50711
}

\begin{abstract}
The issue to be discussed in this article is the internalisation process of international human rights standards into domestic forum through the judicial review mechanism of the constitutionality of legislation by the MKRI. This article argues that MKRI should consider international human rights standards in reviewing the constitutionality of legislation based on Ch. XA of the UUD NRI 1945. The argument based on the prescription that the international human rights standard are binding on States and requiring them to conform their laws and their official behavior to the international norm.
\end{abstract}

Keywords: internalisation, international human rights, MKRI.

\section{Intisari}

Tulisan ini membahas isu proses internalisasi standar HAM internasional dalam forum domestik melalui mekanisme pengujian konstitusionalitas undang-undang oleh MKRI. Tulisan ini berargumen bahwa MKRI seyogianya mempertimbangkan standar HAM internasional dalam menguji konstitusionalitas undangundang berdasarkan Bab XA UUD NRI 1945. Argumen itu didasarkan pada preskripsi bahwa standar HAM internasional berlaku/mengikat kepada negara dan mensyaratkannya untuk menyesuaikan undangundang beserta tindakan pejabatnya dengan kaidah HAM internasional tersebut

Kata Kunci: internalisasi,HAM internasional, MKRI.

\section{Pokok Muatan}

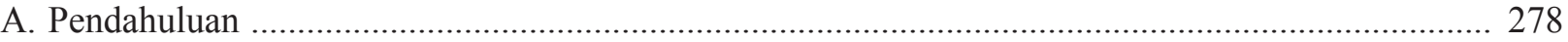

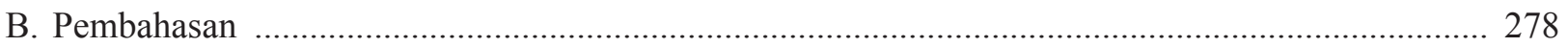

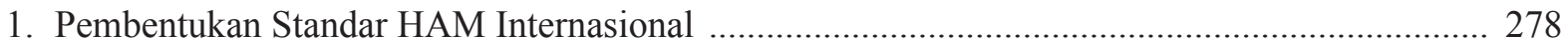

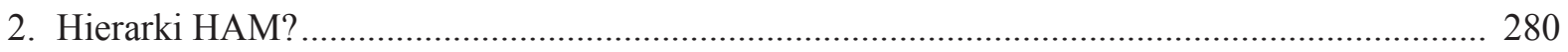

3. Keberlakuan Standar HAM Internasional terhadap MKRI ..................................................... 282

4. Isu Teknis Internalisasi Standar HAM Internasional dalam Pengujian Konstitusionalitas

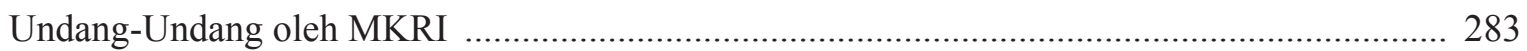

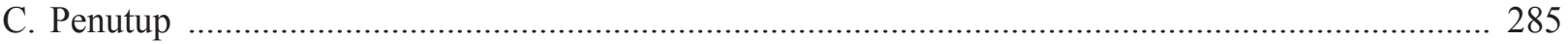

Alamat korespondensi: titonslamet@gmail.com. 


\section{A. Pendahuluan}

Tulisan ini bertujuan mendiskusikan isu hubungan antara standar HAM internasional dengan praktek pengujian konstitusionalitas undangundang di Indonesia oleh Mahkamah Konstitusi Republik Indonesia (MKRI). Pembahasan ini sangat relevan karena kecenderungan praktek pengujian konstitusionalitas undang-undang oleh MKRI yang lebih didominasi isu HAM dengan Bab XA UUD NRI 1945 sebagai dasar pengujian. Berdasarkan hal itu nampak bahwa MKRI lebih menyerupai human rights court. ${ }^{1}$

Terkait isu di atas maka tulisan ini berargumen supaya MKRI mengacu pada standar HAM internasional ketika mempertimbangkan kasus-kasus pengujian konstitusionalitas undangundang berdasarkan Bab XA UUD NRI 1945. Argumen tersebut didasari asumsi bahwa standar HAM internasional berlaku dan mengikat semua negara, menciptakan kewajiban internasional baik melalui perjanjian internasional maupun kebiasaan internasional. Tindakan yang bertentangan dengan kewajiban tersebut, termasuk putusan MKRI, adalah perbuatan melanggar hukum internasional yang berpotensi menimbulkan isu pertanggungjawaban internasional.

Untuk sampai pada argumen di atas maka pembahasan akan diawali tentang proses pembentukan standar HAM internasional dan perkembangan internasionalisasinya serta isu hierarki dalam jenis-jenis HAM yang dicakup. Isu hierarki sangat penting karena menentukan sifat otoritatif dari kewajiban internasional HAM negara yang padabatastertentuhalituberpotensimemancing concern masyarakat internasional untuk bereaksi atas pelanggaran oleh negara. Selanjutnya dibahas pula status standar HAM internasional sebagai sumber hukum yang otoritatif dalam pengujian yudisial konstitusionalitas undang-undang selain
Bab XA UUD NRI 1945. Argumen untuk itu adalah HAM merupakan kaidah universal, atau meminjam pernyataan The Universal Declaration of Human Rights sebagai common standard of achievement for all peoples and for all nations. Status ini bukan retorika, tetapi kaidah yang seyogianya memiliki kekuatan mengikat (the binding force of law).

\section{B. Pembahasan}

\section{Pembentukan Standar HAM Internasional}

Hukum internasional tentang HAM sama seperti hukum internasional pada umumnya yang memiliki sifat dan keterbatasan yang tidak dapat diperbandingkan dengan hukum nasional, terutama dengan ciri khasnya: "international law is a horizontal legal system, lacking a supreme authority, the centralization of the use of force, and a differentiation of the three basic functions of lawmaking, law determination, and law enforcement typically entrusted to central organs." 2 Pendapat tersebut masih valid karena belum ada perubahan signifikan dalam struktur masyarakat internasional serta asas-asasnya. Sebagai implikasinya, proses law-making untuk menghasilkan hukum internasional sangat bergantung pada karakternya sebagai horizontal legal system. Dalam sistem tersebut, proses law-making sangat bergantung pada negara-negara dalam fungsi gandanya: sebagai pembentuk hukum internasional, dan, pada analisis akhir, sebagai subjek hukum internasional.

Lepas dari kelemahannya, hukum internasional pada hakikatnya tetap fungsional karena mayoritas subjeknya patuh ketimbang tidak. Fenomena tersebut dijustifikasi oleh the rational choice theory yang menjelaskan bekerjanya hukum internasional serta kepatuhan negara terhadapnya. Menurut Andrew T. Guzman:

The basics of the theory are simple and rely

\footnotetext{
Tentang argumen MKRI sebagai human rights court lihat Titon Slamet Kurnia, "Mahkamah Konstitusi sebagai Human Rights Court", Jurnal Konstitusi, Vol. 11, 2014, hlm. 149-167; untuk isu lebih spesifik dalam kaitan dengan hak untuk bebas dari diskriminasi sebagai HAM lihat Titon Slamet Kurnia, "Mahkamah Konstitusi dan Hak untuk Bebas dari Perlakuan Diskriminasi," Jurnal Konstitusi, Vol. 12, 2015, hlm. 2142. Untuk pembahasan lebih umum lihat Titon Slamet Kurnia, 2013, Mahkamah Konstitusi Republik Indonesia: Sang Penjaga HAM (The Guardian of Human Rights), Alumni, Bandung.

Peter Malanczuk, 2002, Akehurst's Modern Introduction to International Law, Routledge, New York-London, hlm. 3.
} 
on the three ways a violation of international law can generate costs for a State (the Three $R s)$ : reputation, reciprocal noncompliance, and retaliation. A State that does not comply with its international legal obligations may suffer because it finds it more difficult to make credible international commitments or benefit from international law in the future (reputation); because other States terminate their own compliance (reciprocity); or because other States punish it, even when doing so is costly (retaliation). Each of the Three Rs of Compliance can increase the costs of violation and, therefore, promote cooperation. ${ }^{3}$

Selanjutnya akan didiskusikan di sini proses internasionalisasi HAM, yaitu international law-making untuk menghasilkan standar HAM internasional. Starting point-nya adalah kondisi pasca Perang Dunia II dikaitkan dengan peran PBB. Dibandingkan dengan hukum internasional secara umum, hukum internasional tentang HAM memiliki kekhasan terkait dengan kepentingan yang dilindungi serta penerima manfaat dari perlindungan itu. Hukum internasional tentang HAM tidak ditujukan pada kepentingan negara, tetapi pada kepentingan individu warga negara dalam hubungan dengan negaranya sendiri. Negara lain memiliki kepentingan dalam pengawasan dan penegakannya atas dasar solidaritas karena sama-sama terikat oleh kewajiban hukum yang ditimbulkan oleh hukum internasional tentang HAM, dan bukan kepentingan materiil spesifik karena pelanggaran HAM tersebut merugikan dirinya. ${ }^{4}$

Secara historis, perkembangan standar HAM internasional memiliki kesinambungan dengan hukum nasional yaitu hukum tata negara sebagai bidang hukum yang mengatur hubungan antara negara dengan warga negaranya. ${ }^{5}$ Internasionalisasi HAM yang berlangsung secara masif pasca Perang
Dunia II dipicu oleh kekejaman rezim Nazi sebelum dan selama perang terhadap penduduk sipil, warganya sendiri keturunan Yahudi. Reaksi pertama masyarakat internasional (Sekutu sebagai pemenang perang) adalah mendirikan pengadilan kejahatan internasional untuk mengadili para pimpinan Nazi dengan jenis kejahatan baru yaitu genocide dan crimes against humanity di samping war crimes. Penerapan crimes against humanity terhadap para pimpinan Nazi dan relevansinya dengan inisiasi proses international law-making dalam meletakkan standar HAM internasional ditanggapi oleh Lauterpacht berikut ini:

Crimes against humanity are crimes regardless of whether they were committed in accordance with and in obedience to the national law of the accused. Such acts were deemed to violate the sanctity of human personality to such a degree as to make irrelevant reliance upon the law of the State which ordered them. To lay down that crimes against humanity are punishable is, therefore, to assert the existence of rights of man grounded in a law superior to the law of the State. ${ }^{6}$

Seperti pada proses international law-making secara umum, proses international law-making untuk menghasilkan standar HAM internasional juga bertumpu pada aktivitas-aktivitas lawmaking seperti: kebiasaan internasional, perjanjian internasional, Resolusi-resolusi Majelis Umum PBB, maupun oleh putusan yudisial internasional. ${ }^{7}$ Tentang hal itu Henkin mengatakan: "Surely since World War II, there has been a significant growth of international agreements containing human rights norms binding on the parties; probably, too, there has been a growth of some customary international human rights norms binding on all States." Produk-produk hukum perjanjian internasional

\footnotetext{
Andrew T. Guzman, 2008, How International Law Works: A Rational Choice Theory, Oxford University Press, Oxford, hlm. 224. Louis Henkin, 1988, The Rights of Man Today, Center for the Study of Human Rights-Columbia University, New York, hlm. 102. Ibid., hlm. 31-88.

Hersch Lauterpacht, 1950, International Law and Human Rights, Steven and Sons, London, hlm. 36.

Louis Henkin, "The Politics of Law-Making" dalam Charlotte Ku \& Paul F. Diehl, 1998, International Law: Contemporary and Classic Readings, Lynne Rienner Publishers, Boulder-Colorado, hlm. 20.

Louis Henkin, Op.cit., hlm. 22.
} 
dan Resolusi-resolusi Majelis Umum PBB tentang HAM saat ini merupakan sumber hukum utama dalam standar HAM internasional. Melengkapi eksistensi dari perjanjian internasional tentang HAM adalah kebiasaan internasional.

\section{Hierarki HAM?}

Dalam mendiskusikan isu keterikatan negara terhadap kewajiban internasional HAM, status kewajiban tersebut sangat penting untuk dipertimbangkan, khususnya efek keberlakuan erga omnes dan jus cogens kewajiban tersebut. Karakter erga omnes dari kewajiban internasional, dalam hal ini termasuk perlindungan HAM, mengandung dua konsekuensi normatif yaitu universalitas dan solidaritas. Ragazzi menyatakan:

The first one is universality, in the sense that obligations erga omnes are binding on all States without exception. The second one is solidarity, in the sense that every State is deemed to have a legal interest in their protection. ${ }^{9}$

Konsep kewajiban erga omnes berasal dari obiter dictum putusan The Case Concerning the Barcelona Traction, Light and Power Co., Ltd. antara Belgium v. Spain (1970) oleh The International Court of Justice yang menyatakan:

An essential distinction should be drawn between the obligations of a State towards the international community as a whole, and those arising vis-a-vis another State in the field of diplomatic protection. By their very nature, the former are the concern of all States. In view of the importance of the rights involved, all States can be held to have a legal interest in their protection; they are obligations erga omnes. ${ }^{10}$
Seperti dinyatakan oleh the International Court of Justice, kewajiban internasional yang erga omnes adalah kewajiban internasional khusus yang berbeda dengan kewajiban internasional pada umumnya yang bersifat resiprokal serta didasari persetujuan spesifik supaya dapat berlaku atau mengikat kepada negara. ${ }^{11}$ Ratio legis-nya dinyatakan oleh Tams: "Obligations erga omnes differ from other obligations of general international law in that they protect values of heightened importance." 12

Konsep jus cogens atau peremptory norms secara formal dinyatakan oleh Art. 53 the Vienna Convention on the Law of Treaties (1969) dengan pengertian: "A norm accepted and recognized by the international community of States as a whole as a norm from which no derogation is permitted and which can be modified only by a subsequent norm of general international law having the same character." Konteks eksistensinya dalam kerangka Art. 64 The Vienna Convention on the Law of Treaties adalah syarat kebatalan suatu perjanjian internasional. Namun dalam praktek, konsep jus cogens telah digunakan melampaui konteks asalnya tersebut. ${ }^{13}$ Seiderman secara spesifik mengkonsepsikan fungsinya seperti konstitusi: "Jus cogens is not simply a device relevant to the law of treaties, but that it also governs and limits the formation of customary international law and the expression of unilateral or collective State behavior." 14

Baik konsep erga omnes maupun jus cogens pada hakikatnya mengandung kesamaan esensi dalam rangka menentukan hierarki pada kewajibankewajiban internasional yang berlaku sehubungan aspek substantifnya, bukan aspek formalnya,

\footnotetext{
Maurizio Ragazzi, 1997, The Concept of International Obligations Erga Omnes, Clarendon Press, Oxford, hlm. 17. Erga Omnes and Other Rules-The Identification of Fundamental Norms" dalam Christian Tomuschat \& Jean-Marc Thouvenin, 2006, The Fundamental Rules of the International Legal Order: Jus Cogens and Obligations Erga Omnes, Martinus Nijhoff Publishers, Leiden-Boston, hlm. 21-40. Hierarki secara formal tidak mungkin karena hukum internasional tidak mengenal sistem peraturan perundang-undangan seperti pada hukum nasional.
} 
dengan basis perlindungan terhadap kepentingan sangat fundamental dari masyarakat internasional (basic moral values atau the viability of a community of States). ${ }^{15}$ Artinya, melekatnya konsep-konsep tersebut sebagai status kewajiban internasional tertentu memiliki efek konstitusional berupa peningkatan status keberlakuan kewajiban tersebut. Atau, menurut Theodor Meron, konsep hierarki memberikan penekanan bahwa: "One cannot deny that quality labels are a useful indication of the importance attached to particular rights. They strengthen the case against violation of such rights. Hierarchical terms constitute a warning sign that the international community will not accept any breach of those rights." 16

Hal ini sangat rasional karena tidak semua kewajiban internasional memiliki karakter erga omnes dan jus cogens sehingga a fortiori pada kewajiban internasional yang melekat dengan karakter tersebut akan memiliki implikasi yuridis berbeda yaitu berlaku tuntutan untuk lebih diprioritaskan ketimbang kewajiban internasional yang lain. Berkaitan dengan HAM Seiderman mengemukakan bahwa tidak semua HAM dapat berkarakter sebagai kewajiban erga omnes dan jus cogens. Kandidat paling kurang kontroversial yang potensial berkarakter sebagai kewajiban erga omnes maupun jus cogens adalah HAM dengan kualifikasi tertentu: non-derogable rights. ${ }^{17}$ Kaidah HAM dengan kualifikasi non-derogable rights yang sekaligus berkarakter erga omnes dan jus cogens adalah: larangan summary, arbitrary or extra judicial killing; larangan judicial executions of juvenile offenders; larangan genocide; larangan enforced dissappearances; larangan torture; larangan cruel, inhuman or degrading treatment or punishment; larangan diskriminasi (racial, gender, religiuous, linguistic, social group, minority); larangan arbitrary detention; larangan perbudakan; larangan penerapan retroactive criminal liability. ${ }^{18}$
Sebagai pembanding adalah konsep pelanggaran HAM yang akan diperlakukan sebagai pelanggaran hukum internasional secara umum (tidak memandang apakah negara yang melakukan pelanggaran terikat oleh perjanjian internasional yang melarang tindakan tersebut atau tidak) menurut the Restatement (Third) of the Foreign Relations Law of the United States (Revised) Sec. 702: ${ }^{19}$

A State violates international law if, as a matter of State policy, it practices, encourages, or condones:

a. Genocide;

b. Slavery or slave trade;

c. The murder or causing the disap pearance of individuals;

d. Torture or other cruel, inhuman or degrading treatment or punishment,

e. Prolonged arbitrary detention;

f. Systematic racial discrimination, or;

g. Consistent pattern of gross violations of internationally recognized human rights.

Menjelaskan pengertian Sec. 702, Comment huruf 'm pada Sec. 702 menyatakan:

The acts enumerated in clauses (a) to (f) are violations of customary law even if the practice is not consistent, or not part of a 'pattern' and those acts are inherently 'gross'violations of human rights. Clause (g) includes other infringements of recognized human rights that are not violations of customary law when committed singly or sporadically (although they may be forbidden to State parties to the international covenant or other particular agreements); they become violations of customary law if the State is guilty of a 'consistent pattern of gross violations' as State policy. ${ }^{20}$

Pendapat di atas meletakkan tingkat keseriusan pelanggaran HAM dalam dua kategori, yaitu berdasarkan jenis hak yang dilanggar dan berdasarkan taraf pelanggarannya. Sebagaimana nampak di atas, tidak semua pelanggaran HAM akan menjadi international concern (dianggap

\footnotetext{
Theodor Meron, "On a Hierarchy of International Human Rights”, The American Journal of International Law, Vol. 80, 1986, hlm. 22.

Ian D. Seiderman, Ibid., hlm. 121, 131-135.

Ibid., hlm. 281.

19 Louis Henkin, et.al., 1987, International Law: Cases and Materials, West Publishing Co., St. Paul-Minn., hlm. 996-997.

20 Ibid., hlm. 1000.
} 
sebagai pelanggaran terhadap hukum internasional yang berlaku umum yaitu pelanggaran kebiasaan internasional). Jenis HAM yang dicakup di dalamnya adalah jenis HAM spesifik yang sinonim dengan non-derogable rights. Di luar pelanggaran terhadap hak-hak spesifik tersebut, pelanggaran HAM yang akan menjadi international concern adalah pelanggaran yang dilakukan dengan consistent pattern.

Dengan demikian, sebagai kesimpulan, keberlakuan katagori HAM yang non-derogable berimplikasi menuntut negara untuk memiliki taraf kepatuhan lebih tinggi ketimbang terhadap HAM yang bukan non-derogable. Akan tetapi ini tidak berarti bahwa terhadap HAM yang bukan non-derogable maka negara boleh tidak mematuhi kewajibannya. Apapun katagori HAMnya, tetap menuntut kepatuhan negara yang sama atas kewajiban internasionalnya. Implikasi yuridis spesifik dari status erga omnes dan jus cogens pada keberlakuan standar HAM internasional yang berkatagori non-derogable rights adalah pengenduran the principle of unanimity (yaitu: no State is bound by any proposed norm or regulation without its consent, though consent once given is binding and cannot be withdrawn at will $\left.{ }^{21}\right)$. Negara tidak dapat menyangkal keberlakuan standar HAM internasional berstatus erga omnes dan jus cogens tersebut dengan argumen tidak pernah menyatakan diri terikat pada kewajiban HAM tersebut. Inilah makna terpenting dari isu hierarki HAM tersebut. Pada analisis akhir, negara lain dapat bersikap lebih tegas kepada negara yang melanggar atau tidak patuh mengingat pelanggaran tersebut demikian substansial.

\section{Keberlakuan Standar HAM Internasional}

\section{terhadap MKRI}

Berdasarkan kerangka hukum HAM yang berlaku setiap orang menikmati perlindungan rangkap yang diberikan oleh sistem hukum nasionalnya dan oleh sistem hukum internasional yang berfungsi melengkapi perlindungan hukum nasional manakala perlindungan tersebut tidak memadai. ${ }^{22}$ Isu utama di sini adalah internalisasi standar HAM internasional sehubungan interpretasi Bab XA UUD NRI 1945 oleh MKRI dalam pengujian konstitusionalitas undang-undang. Hal itu menjadi isu karena UUD NRI 1945 tidak memiliki ketentuan seperti Sec. 39 Constitution of the Republic of South Africa (1996): “(1) When interpreting the Bill of Rights, (a) a court, tribunal or forum must promote the values that underlie an open and democratic society based on human dignity, equality and freedom; (b) must consider international law; (c) may consider foreign law."23

Frase yang perlu penekanan dari ketentuan di atas ialah "must consider international law." Hal ini melegitimasi upaya hakim untuk mengacu pada hukum internasional sebagai pertimbangan putusannya. Kondisi berbeda dialami Indonesia di mana UUD NRI 1945 tidak mengotorisasi secara eksplisit penggunaan hukum internasional sebagai sumber hukum bagi pengadilan, termasuk bagi MKRI dalam melakukan pengujian konstitusionalitas undang-undang.

Atas isu tersebut saya berargumen bahwa interpretasi Bab XA UUD NRI 1945 oleh MKRI seyogianya dilakukan konsisten dengan hukum internasional yang membebankan kewajiban internasional dalam rangka perlindungan HAM kepada Indonesia. Hal itu sejalan dengan prinsip dalam perspektif internasional bahwa: "The international law of human rights is higher positive law, binding on States that adhere to it regardless of their own constitutions or other laws, and requiring them to conform their laws and their official behavior to the international norm." 24 Preskripsi tersebut dapat dikecualikan jika Indonesia mampu membuktikan sebaliknya, yaitu membuktikan noneksistensi standar HAM internasional, sehingga

\footnotetext{
Louis Henkin, "The Politics Of Law Making”, Op.cit., hlm. 20.

Louis Henkin, 1988, The Rights of Man Today, Op.cit., hlm. 95.

Mark S. Kende, 2009, Constitutional Rights in Two Worlds: South Africa and the United States, Cambridge University Press, Cambridge, hlm. 8 .

24 Louis Henkin, 1988, The Rights of Man Today, Op.cit., hlm. 22.
} 
implikasi yuridisnya bagi Indonesia adalah tidak ada kewajiban internasional yang berlaku. Atau, kemungkinan lain, jika dengan interpretasinya ternyata Indonesia mampu memberikan perlindungan lebih baik terhadap HAM ketimbang yang diberikan oleh standar HAM internasional.

Sejauh ini Indonesia telah berpartisipasi dalam beberapa perjanjian internasional tentang HAM yang antara lain meliputi: International Convention on the Elimination of All Forms of Racial Discrimination; International Covenant on Civil and Political Rights; International Covenant on Economic, Social and Cultural Rights; Convention Against Torture and Other Cruel, Inhuman or Degrading Treatment or Punishment; Convention on the Elimination of All Forms of Discrimination Against Women; Convention on the Rights of the Child. Selain terikat oleh perjanjian internasional tersebut, Indonesia juga terikat oleh kebiasaan internasional tentang HAM. MKRI sebagai salah satu unsur dari pemerintah Negara Republik Indonesia seharusnya lebih memperkuat komitmen keterikatan Indonesia terhadap standar HAM internasional, khususnya untuk HAM yang non-derogable karena memiliki karakter erga omnes dan jus cogens, dengan memberikan efek yuridis atas keberlakuan standar HAM tersebut dalam melakukan pengujian konstitusionalitas undang-undang.

Apapun jenis sumber hukumnya, kewajiban internasional yang timbul pada hakikatnya mengandung konsekuensi yuridis yang sama: pelanggarannya secara substansial adalah perbuatan melanggar hukum internasional. Konsekuensi yuridis tersebut tidak dapat dihindari oleh Indonesia kecuali memang sengaja memilih melakukan itu (yang secara moral tercela karena tidak mematuhi kewajibannya dan secara yuridis dapat menimbulkan pertanggungjawaban internasional negara). Pada prinsipnya, perbedaan yang ada terkait dengan jenisjenis sumber hukum hanya relevan untuk menjawab isu prosedural penuntutan pertanggungjawaban internasional negara. ${ }^{25}$ Berdasarkan praktek negara ditemukan bukti ekstensif bahwa negara-negara tidak berkeberatan untuk melakukan tindakan diplomatik guna melindungi warga negara asing dari pemerintahnya sendiri sebagai upaya penegakan HAM dalam menuntut pertanggungjawaban negara pelanggar. ${ }^{26}$

\section{Isu Teknis Internalisasi Standar HAM Internasional dalam Pengujian Konsti- tusionalitas Undang-Undang oleh MKRI}

Setiap negara umumnya menghadapi isu teknis berkenaan dengan penerapan hukum internasional dalam forum domestik sehingga hal ini memunculkan praktek ajudikasi yang berbeda antar satu negara dengan negara lain. Pada tataran teoretis fenomena ini dijelaskan oleh teori monisme dan teori dualisme. Pada tataran praktis, solusi yang digunakan adalah tindakan inkorporasi dan transformasi. ${ }^{27}$ Atas kesulitan teknis tersebut saya berangkat dari kaidah paling fundamental yaitu:

International law is binding on all States, and every State is obliged to give effect to it. While the international obligation is upon State, not upon any particular branch, institution, or individual member of its government, the State is responsible for violations by any branch or subdivision of its government or by any official (and in some contexts also for acts and omissions by private individuals). The State is responsible to assure that its government, its constitution, and its laws enable it to carry out its international obligations. $^{28}$

Konsisten dengan itu hukum internasional tidak mempermasalahkan segi teknis penerapan hukum internasional pada forum domestik. Preskripsi yang berlaku umum adalah negara tidak boleh gagal dalam menjalankan kewajiban

\footnotetext{
Titon Slamet Kurnia, 2005, Reparasi (Reparation) terhadap Korban Pelanggaran HAM di Indonesia, Citra Aditya Bakti, Bandung, hlm. 175-264

26 Menno T. Kamminga, 1992, Inter-State Accountability for Violations of Human Rights, University of Pennsylvania Press, Philadelphia, hlm. 6-56.

7 Peter Malanczuk, Op.cit., hlm. 63-71. Lihat juga Malcolm N. Shaw, Op.cit., hlm. 129-194.

28 Louis Henkin, et.al., Op.cit., hlm. 137.
} 
internasionalnya: "As long as a State carries out its obligations, how it does so is not the concern of international law." Tetapi sebaliknya, "The exercise of jurisdiction by a domestic court contrary to the limitations of international law would constitute a violation by the State." ${ }^{29}$

Dalam internalisasi hukum internasional oleh forum domestik, teori inkorporasi menjelaskan: " $A$ rule of international law becomes part of municipal law without the need of express adoption." Situasi pengecualian untuk inkorporasi yaitu jika: "There is some clear provision of municipal law, such as a statute or judicial decision, which precludes the use of the international law rule by the municipal court." ${ }^{30}$ Sementara menurut teori transformasi, "Rules of international law do not become part of municipal law until they have been expressly adopted by the State." Secara teknis implikasi dari keharusan adanya express adoption oleh negara terhadap kaidah hukum internasional yaitu: " $A$ municipal court cannot apply a particular rule of international law until that particular rule has been deliberately 'transformed' into municipal law in the appropriate manner, as by legislation." 31

Akan tetapi hal ini tidak menghalangi keberlakuan asas umum yang dikemukakan di atas bahwa penerapan hukum internasional pada aras domestik dengan kewajiban untuk patuh pada hukum internasional pada hakikatnya adalah dua kondisi berbeda. Asas hukum internasional yang menguatkan dalil ini: "A State cannot plead its own law as an excuse for non-compliance with international law." 32 Dengan pengertian lain, menurut Shaw: "It is no defence to a breach of an international obligation to argue that the State acted in such a manner because it was following the dictates of its own municipal laws." 33

Secara yuridis, inkorporasi dan transformasi merupakan isu hukum tata negara. Dalam kasus Indonesia, UUD NRI 1945 tidak mempreskripsi isu ini secara eksplisit. Namun demikian, dalam pengujian undang-undang berdasarkan Bab XA UUD NRI 1945 oleh MKRI, penerapan hukum internasional dapat dilakukan dengan inkorporasi (termasuk perjanjian internasional di mana Indonesia telah menyatakan diri sebagai negara pihak) karena yang menjadi isu adalah kompatibilitas interpretasi kaidah hukum nasional (interpretasi konstitusi) terhadap hukum internasional. ${ }^{34}$ Untuk menghindari terjadinya resistensi oleh pandangan yang cenderung nasionalistik, penerapan tersebut hendaknya dimaknai bukan dalam pengertian hukum internasional sebagai kaidah yang menentukan konstitusionalitas undang-undang.

Pendekatan ini mengacu konsep international constitution dari Sarah Cleveland..$^{35}$ Pendekatan ini juga sejalan dengan konsep transnational legal process dari Harold Koh yang bertujuan untuk mendorong dipatuhinya hukum internasional melalui inkorporasi ke dalam domestic legal and political structures.$^{36}$ Kedua pendekatan diterapkan secara eksplisit oleh The Constitution of the Republic of South Africa 1996, dan bukan mustahil dapat diterapkan pula pada kasus Indonesia walau tanpa otorisasi eksplisit UUD NRI 1945. Dalam konteks demikian maka isu substansialnya ialah konsep konstitusi Indonesia perlu diperluas cakupan maknanya tidak hanya sebatas apa yang dinyatakan secara eksplisit oleh UUD NRI 1945.

Asas dan kaidah hukum internasional

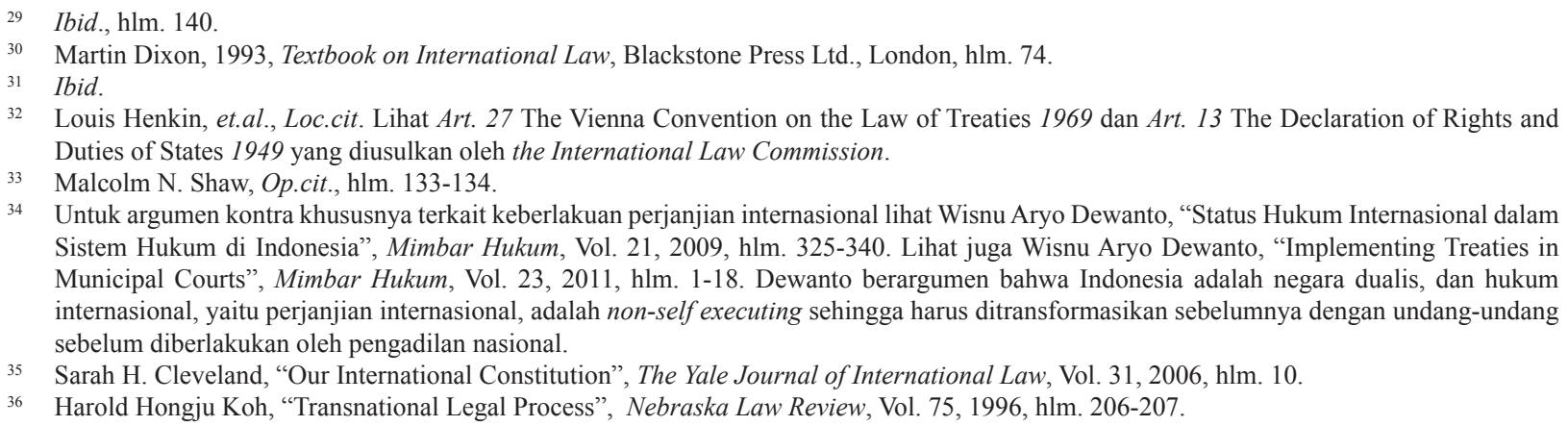

Untuk argumen kontra khususnya terkait keberlakuan perjanjian internasional lihat Wisnu Aryo Dewanto, "Status Hukum Internasional dalam Sistem Hukum di Indonesia", Mimbar Hukum, Vol. 21, 2009, hlm. 325-340. Lihat juga Wisnu Aryo Dewanto, "Implementing Treaties in Municipal Courts", Mimbar Hukum, Vol. 23, 2011, hlm. 1-18. Dewanto berargumen bahwa Indonesia adalah negara dualis, dan hukum internasional, yaitu perjanjian internasional, adalah non-self executing sehingga harus ditransformasikan sebelumnya dengan undang-undang sebelum diberlakukan oleh pengadilan nasional.

35 Sarah H. Cleveland, “Our International Constitution”, The Yale Journal of International Law, Vol. 31, 2006, hlm. 10.

36 Harold Hongju Koh, “Transnational Legal Process”, Nebraska Law Review, Vol. 75, 1996, hlm. 206-207. 
dapat menjadi bagian dari konstitusi kita karena hukum internasional adalah hukum bagi Indonesia sepanjang tidak bertentangan dengan asas-asas fundamental UUD NRI 1945 sendiri. Jika selama ini terjadi silang pendapat tentang visi internasional dari UUD NRI 1945 apakah monis atau dualis, maka penulis berpendapat sebaliknya bahwa perdebatan tersebut kurang relevan. Bukan monis atau dualis yang hukum, tetapi apakah hukum internasional itu sendiri adalah hukum. Inilah faktor esensial yang harus lebih dipertimbangkan secara konstitusional sebagai kaidah bagi konstitusi kita, UUD NRI 1945. Situasi demikian mirip dengan pandangan The Supreme Court of the United States dalam kasus The Paquete Habana (1900) yang menyatakan: "International law is part of our law, and must be ascertained and administered by the courts of justice of appropriate jurisdiction, as often as questions of right depending upon it are duly presented for their determination?" ${ }^{77}$ Dalam kasus ini penulis setuju dengan Harold Koh yang berpendapat terkait isu penggunaan hukum internasional dalam rangka interpretasi konstitusi yang menyatakan: "Particular provisions of our Constitution should be construed with decent respect for international and foreign comparative law." 38 Pendapat Harold Koh dibangun atas dasar prapemahaman mengenai pentingnya kompatibilitas hukum nasional dengan hukum internasional. Untuk itu Harold Koh berargumen jika situasi sebaliknya yang terjadi maka: "for any nation consciously to ignore global standards not only would ensure constant frictions with the rest of the world, but also would diminish that nation's ability to invoke those international rules that served its own national purposes." 39

Lepas dari isu yang lebih bersifat teknisformal, pertanyaan substantif terkait dengan internalisasi standar HAM internasional dalam pengujian konstitusionalitas undang-undang oleh MKRI adalah mana yang lebih baik dalam memberikan perlindungan HAM: hukum internasional atau hukum nasional? MKRI harus memiliki sensitivitas dalam menjawab pertanyaan tersebut supaya tidak terjebak pada argumen formalistik-legalistik bahwa konstitusi Indonesia, UUD NRI 1945, adalah konstitusi dualis, sehingga pengadilan nasional, termasuk MKRI, tidak boleh serta merta menerapkannya. Asas substansial yang harus lebih diprioritaskan di sini adalah supremasi atau superioritas HAM (atau mengikuti pernyataan Lauterpacht yang telah dikutip sebelumnya: "The existence of rights of man grounded in a law superior to the law of the State"). Implikasinya, jika hukum internasional memberikan perlindungan lebih baik terhadap HAM maka MKRI harus memprioritaskannya. Dengan demikian argumen untuk internalisasi standar HAM internasional dalam pengujian konstitusionalitas undang-undang oleh MKRI adalah argumen substantif, bukan argumen formal yang masih mempertanyakan apakah UUD NRI 1945 mengikuti teori monisme atau dualisme.

\section{Penutup}

MKRI terikat untuk mempertimbangkan keberlakuan standar HAM internasional dalam kasus-kasus pengujian konstitusionalitas undangundang yang memiliki isu ratione materiae tentang HAM dan dengan dasar pengujian Bab XA UUD NRI 1945. Standar HAM internasional yang wajib dipertimbangkan oleh MKRI secara khusus adalah standar HAM internasional yang telah memperoleh status erga omnes dan jus cogens, dalam hal ini non-derogable rights.

Kekhususan dari standar HAM internasional yang telah memperoleh status erga omnes dan jus cogens adalah pengenduran the principle of unanimity sebagai dasar kekuatan mengikat hukum internasional kepada negara. Terhadap standar HAM internasional berstatus erga omnes dan jus

\footnotetext{
Harold Hongju Koh, "International Law as Part of Our Law", The American Journal of International Law, Vol. 98, 2004, hlm. 43. Ibid., hlm. 56

Ibid., hlm. 44 .
} 
cogens, dalam hal ini non-derogable rights, berlaku presumsi bahwa semua negara dianggap terikat oleh kewajiban internasional tentang HAM tersebut dengan atau tanpa persetujuan mereka sebelumnya. Oleh karena itu, sebagai implikasi yuridisnya,
MKRI harus memberikan efek yuridis keberlakuan kewajiban internasional tentang HAM tersebut dalam pertimbangan hukum putusannya sebagai dasar pengujian bersama dengan Bab XA UUD NRI 1945.

\section{DAFTAR PUSTAKA}

\section{A. Buku}

Dixon, Martin, 1993, Textbook on International Law, Blackstone Press Ltd., London.

Guzman, Andrew T., 2008, How International Law Works: A Rational Choice Theory, Oxford University Press, Oxford.

Henkin, Louis, 1988, The Rights of Man Today, Center for the Study of Human RightsColumbia University, New York.

Henkin, Louis, et.al., 1987, International Law: Cases and Materials, West Publishing Co., St. Paul-Minn.

Kamminga, Menno T., 1992, Inter-State Accountability for Violations of Human Rights, University of Pennsylvania Press, Philadelphia.

Kende, Mark S., 2009, Constitutional Rights in Two Worlds: South Africa and the United States, Cambridge University Press, Cambridge.

Kurnia, Titon Slamet, 2005, Reparasi (Reparation) terhadap Korban Pelanggaran HAM di Indonesia, Citra Aditya Bakti, Bandung. , 2013, Mahkamah Konstitusi Republik Indonesia: Sang Penjaga HAM (The Guardian of Human Rights), Alumni, Bandung.

Lauterpacht, Hersch, 1950, International Law and Human Rights, Steven and Sons, London.

Malanczuk, Peter, 2002, Akehurst's Modern Introduction to International Law, Routledge, New York-London.

Ragazzi, Maurizio, 1997, The Concept of International Obligations Erga Omnes, Clarendon Press, Oxford.

Seiderman, Ian D., 2001, Hierarchy in International
Law: The Human Rights Dimension, Intersentia-Hart, Antwerpen.

Shaw, Malcolm N., 2008, International Law, Cambridge University Press, Cambridge.

Tams, Christian J., 2005, Enforcing Obligations Erga Omnes in International Law, Cambridge University Press, Cambridge.

\section{B. Artikel Jurnal}

Cleveland, Sarah H., "Our International Constitution," The Yale Journal of International Law, Vol. 31, 2006.

Dewanto, Wisnu Aryo, "Status Hukum Internasional dalam Sistem Hukum di Indonesia," Mimbar Hukum, Vol. 21, 2009. , "Implementing Treaties in Municipal Courts," Mimbar Hukum, Vol. 23, 2011.

Koh, Harold Hongju, "Transnational Legal Process," Nebraska Law Review, Vol. 75, 1996.

, "International Law as Part of Our Law," The American Journal of International Law, Vol. 98, 2004.

Kurnia, Titon Slamet, "Mahkamah Konstitusi sebagai Human Rights Court," Jurnal Konstitusi, Vol. 11, 2014.

, "Mahkamah Konstitusi dan Hak untuk Bebas dari Perlakuan Diskriminasi," Jurnal Konstitusi, Vol. 12, 2015.

Meron, Theodor, "On a Hierarchy of International Human Rights," The American Journal of International Law, Vol. 80, 1986.

\section{Artikel dalam Antologi dengan Editor}

Henkin, Louis, "The Politics of Law-Making," dalam Ku, Charlotte, \& Paul F. Diehl, 1998, 
International Law: Contemporary and Classic Readings, Lynne Rienner Publishers, Boulder-Colorado.

Kadelbach, Stefan, "Jus Cogens, Obligations Erga Omnes and Other Rules-The Identification of Fundamental Norms," dalam Tomuschat,
Christian, \& Jean-Marc Thouvenin, 2006, The Fundamental Rules of the International Legal Order: Jus Cogens and Obligations Erga Omnes, Martinus Nijhoff Publishers, Leiden-Boston. 